\title{
Mineral Resources Availability and Global Change
}

\author{
by Friedrich K. Bender
}

Global changes due to human activity are now outpacing those caused by natural processes, according to many observers. This article, originally prepared for the IUGS 25th Anniversary Symposium held earlier this year in Washington, D.C., considers the part played by society's use of mineral resources, including hydrocarbons, soil and water. Examination of the static lifetime of major mineral resources shows that earlier fears of their rapid exhaustion were unfounded. However, the environmental impacts of steps involved in the extraction, processing and use of many minerals are significant, and the author suggests a series of actions that geoscientists can take to ease the situation. (Ed.)

\section{Introduction}

The activities involved in making mineral resources available to society are major contributors to changes in the global environment. Although they are negligible during prospecting and exploring (except for offshore exploration for hydrocarbons), they become obvious during exploitation and even more so during the utilization of such resources, whether directly or through industrial processes. This is true for energy resources, metallic and non-metallic resources, as well as for water and soil. The impact on the environment of the ever-increasing consumption of natural resources is distinctly recorded in the lithosphere, thus challenging the geosciences to solve problems related to global change.

\section{Availability of Mineral Resources}

The availability of mineral commodities depends primarily on the price that people are willing to pay for them. As late as the early seventies, several authors (e.g. Meadows et al., 1972) expressed fears that many minerals would be depleted within a foreseeable period of time. However, it has now become obvious that the lifetime of those natural resources for which demand is increasing can be extended, in some cases considerably. Demand and supply control their price, and elevated prices stimulate exploration and production, a trend that has continued without exception since the beginning of the industrial age more than a hundred years ago. There are no geological reasons to assume that this situation will change in the foreseeable future.

The consumption of oil, for example, has surpassed several times what was earlier regarded as the total reserve. In 1950, world oil reserves were given in the Oil and Gas Journal as $10.6 \times 10^{9} \mathrm{t}$, whereas the cumulative production by $1 \overline{98} 3$, according to the Journal, was already about six times this amount. In 1983 oil reserves, not including those in bituminous rocks, were estimated to amount to $91 \times 10^{9} \mathrm{t}$ (Erdöl Informationsdienst, vol. 37, no., 30, 1984). However, there are indications that at the beginning of the 1990 s the annual discovery rate of new oil reserves will be exceeded by the production rate. This will probably lead to another increase in the price of oil with positive effects on the lifetime of oil reserves, especially since the oil resources in bituminous rocks would become economically more attractive than they are now.

Figure 1 illustrates the development of reserves and the cumulative production and shows that the static lifetime (the "life expectancy" of reserves at the current rate of production; see box - Ed.) of world oil reserves has remained constant at about 30 years. Thus each year, global consumption has been balanced by discoveries of oil, in spite of the fact that consumption has considerably increased.

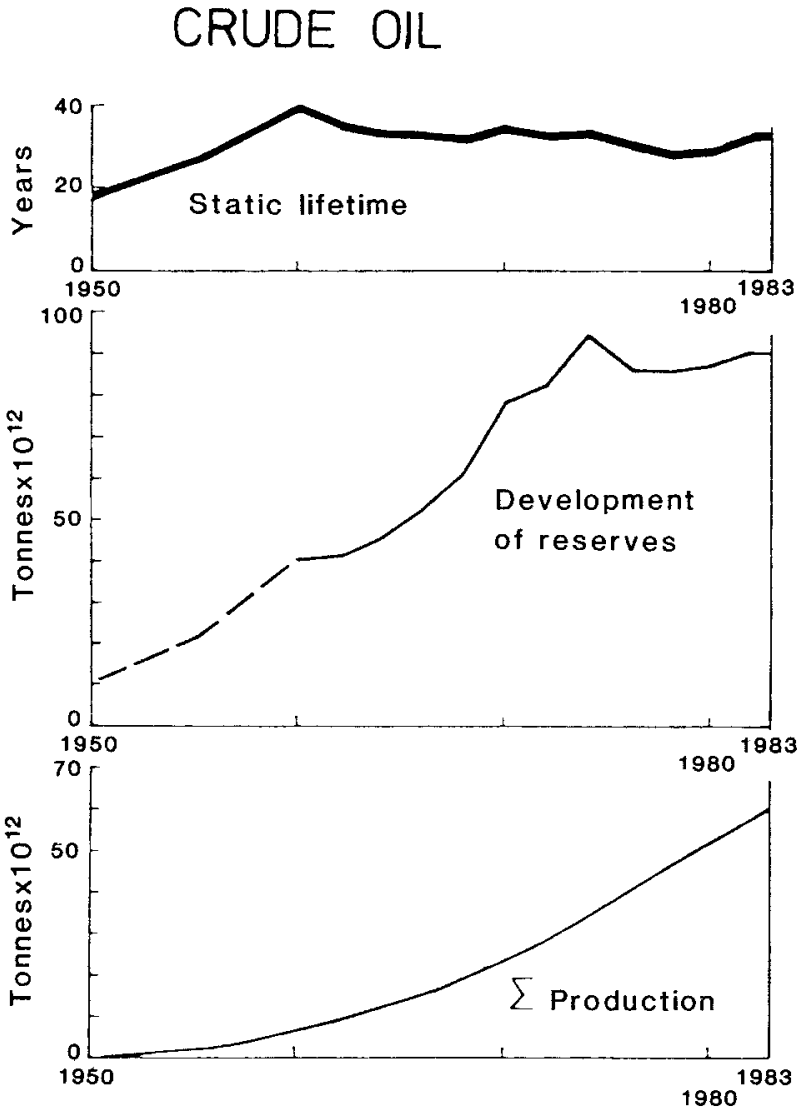

Figure 1: Cumulative oil production and development of oil reserves since 1950. Since about 1955, the static lifetime of the crude oil reserves is constantly around 30 years. After Bender and Delisle (1984). 
The static reserve index (or static lifetime) is the length of time that reserves at any one time will last given the current rate of production. This is not a very meaningful statistic, and it has led to a great deal of confusion in the past. For example, according to Meadows et al. (1972) "This static index is the measure normally used to express future resource availability." This represented a profound misunderstanding of the significance of reserve figures and of the distinction between reserves (known to exist, reasonably well measured and economically exploitable under current conditions) and resources (potentially exploitable if discovered) as they are used in the mineral industry. The changes in the magnitude of Canadian reserves and the static lifetime of seven metals over the past 20 years are illustrated below. Note that reserves have remained relatively constant despite ongoing mining of the resource.

The small fluctuations in the sizes of reserves are related mainly to metal prices and production costs. One notable exception to this pattern is gold, for which reserves have been more than tripled over the last decade despite accelerating production: this reflects the increase in exploration for gold since the price was deregulated. The relative constancy of mineral reserves illustrates that mining companies spend dollars on exploration to delineate reserves sufficiently only to support their production over a limited period of time, perhaps 15 or 20 years. There is no economic incentive to prove-up reserves beyond what will be needed over the medium term future. (After R.A. Price, "Canada's Mineral Resource Potential," 1986, unpublished.)

\section{Canadian Mineral Reserves}

Metal $1967 \quad 1975 \quad \begin{aligned} & 1980 \\ & \left(\text { units*) }^{*}\right.\end{aligned}$

$\begin{array}{lrrrrr}\text { Copper } & 17.7 & 17.0 & 16.4 & 16.0 & 19 \\ \text { Nickel } & 6.5 & 7.3 & 7.2 & 7.2 & 41 \\ \text { Zine } & 28.2 & 28.3 & 28.6 & 26.2 & 26 \\ \text { Lead } & 11.0 & 9.3 & 9.6 & 8.9 & 36 \\ \text { Molybdenum } & 0.5 & 0.3 & 0.6 & 0.4 & 52 \\ \text { Gold } & - & 0.37 & 0.54 & 1.24 & 15 \\ \text { Silver } & - & 28.6 & 31.5 & 31.5 & 26\end{array}$

* Gold units $\left(x 10^{6} \mathrm{~kg}\right)$; silver $\left(\times 10^{3}\right.$ tonnes); all others ( $x 10^{6}$ tonnes).

** Static Reserve Index: current reserves as multiples of 1985 production.

Compared with other energy resources, coal has by far the most important energy potential (Fettweis, 1979, 1981). Its distribution is established to a large extent, and the discovery of large and completely unknown coal deposits of worldwide significance can hardly be expected. The development of the static lifetime of the reserves and cumulative production from 1940 to 1980 is shown in Figure 2. Reserves down to a depth of $2000 \mathrm{~m}$ and a coal seam thickness of $0.3 \mathrm{~m}$ or more comprise about $6900 \times 10^{9} \mathrm{t}$ of hard coal units. Of these, $488 \times 10^{9} \mathrm{t}$ can be mined economically. On the basis of consumption in 1980, hard coal reserves would last for about 200 years, the reserves of sub-bituminous coal for 780 years and of lignite for 280 years.

Uranium reserves had a static lifetime in 1960 of only about twenty years (Fig. 3). The inerease in civilian demand for nuclear fuel in the mid-sixties led to an increase in the uranium price from $\$ 6$ per pound in 1970 to $\$ 43$ in 1979 .

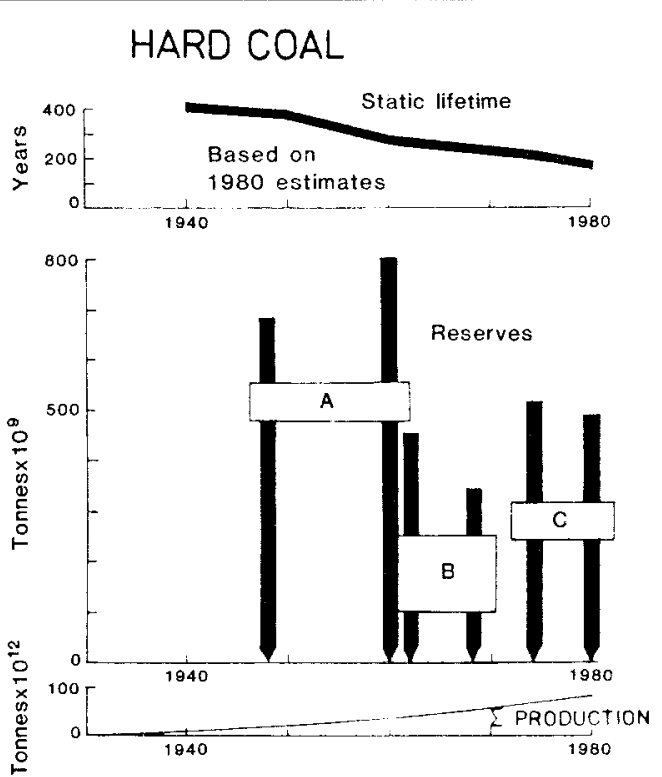

Figure 2: Static lifetime, reserves and cumulative production of hard coal since 1940. After Bender and Delisle (1984). Measured reserves shown in $B C x$ $A$. Boxes $B$ and $C$ show estinates of economically recoverable reserves.
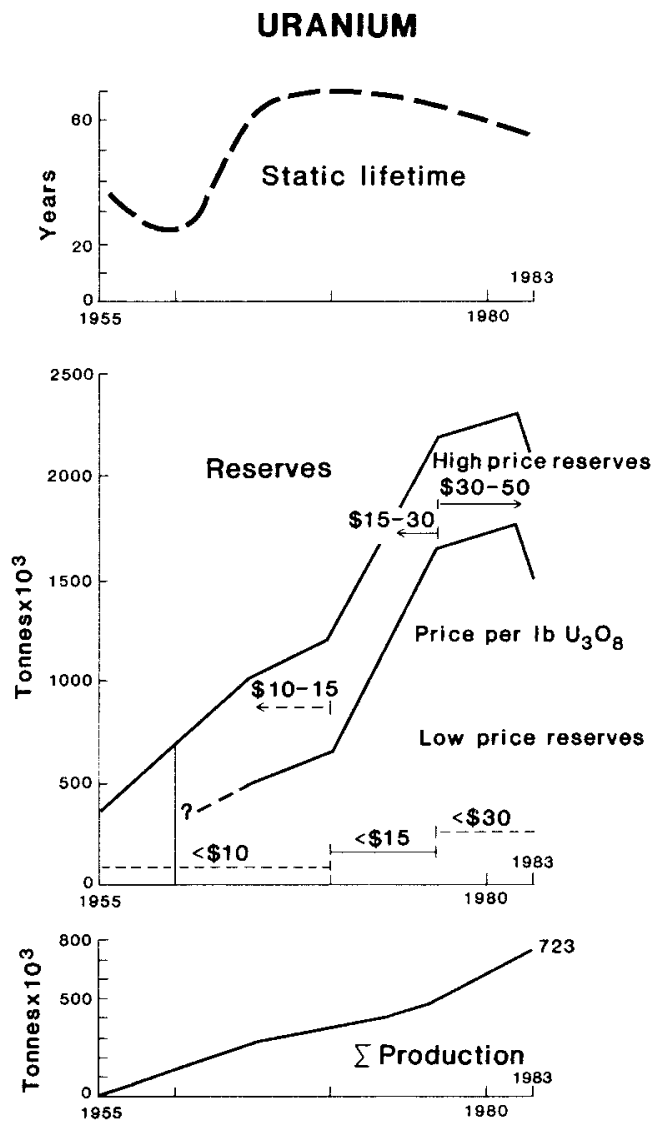

Figure 3: Cumulative production, development ot reserves at different price levels, and static lifetime of uranium since 1955. After Bender ard Delisle (1984). 

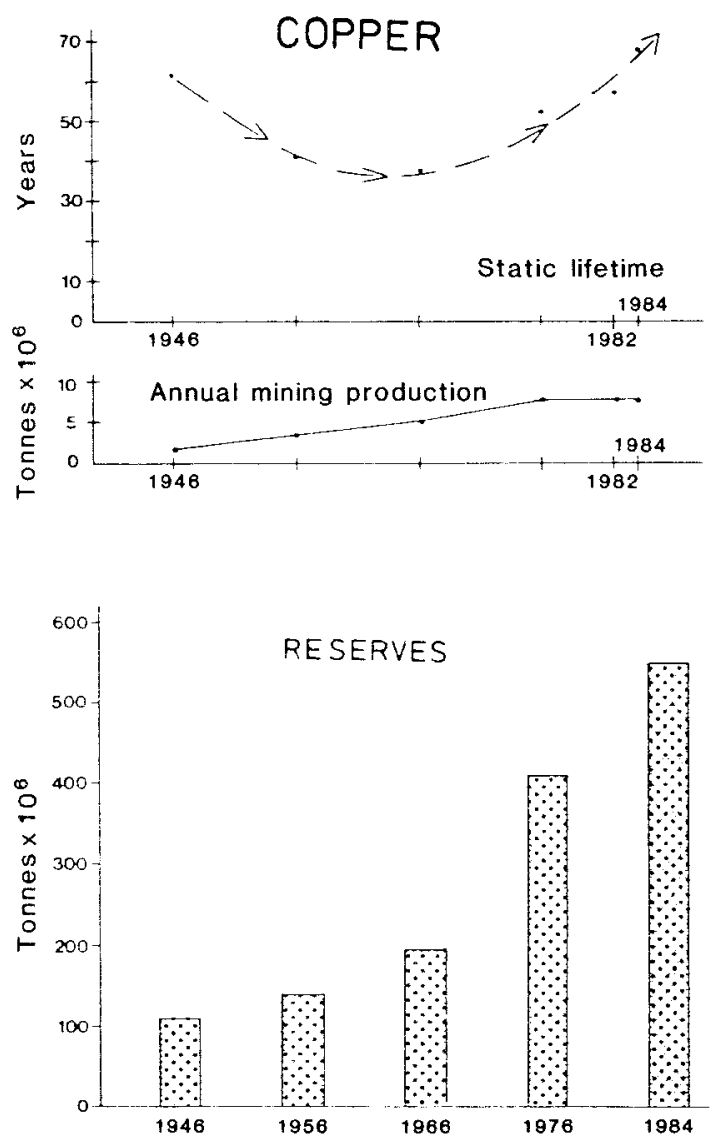

Figure 4: Annual mining production, reserves and static lifetime of copper since 1946. After Bender and Delisle (1984), and Anon. (1980).

This price explosion stimulated the search for uranium all over the world. As a result so much uranium has been found that the static lifetime is now about 50 years, even if minimum prices are taken as a basis.

Consideration of static lifetime of global copper reserves likewise provides no signs of their exhaustion (Fig. 4). At no time since 1946 have there been more demonstrated copper reserves than now. In 1979 , the static lifetime increased to 47 years and even to 68 years in 1983 (Schmidt and Kruszona, 1982), whereas it was only 40 years in 1960 .

Phosphate has been chosen as an example of non-metallic raw materials, since as a fertilizer in agriculture it has a particularly significant role in the feeding of the still rapidly growing world population. Global production of phosphate increased from a little less than $85 \times 10^{6} \mathrm{t}$ of concentrate in 1979 to a maximum of $142 \times 10^{6} \mathrm{t}$ in 1981 . This is what made the considerable success of the "green revolution" in the developing countries possible. As shown in Eigure 5 the static lifetime of phosphate is 260 to 280 years, taking an annual production of from 130 to $140 \times 10^{6}$ $t$ as a basis. The potential phosphate reserves are nearly $157 \times 10^{9}$ t (Anon., 1971, 1980, 1983).

The examples given here make it clear that the shortage of mineral resources apparent in the mid-sixties was only the result of insufficient exploration during previous years. Statements to the contrary do not take into consideration the effect of the price on the reserves situation nor the fact that too little is known about the earth's crust to forecast the exhaustion of mineral deposits. Figure 6 shows the development of the static lifetimes of a number of important commodities; the predictions of the "doomsday prophets" with respect to uranium, zinc, and lead are shown in black.

Near-surface bulk commodities include sand, gravel, and crushed stone, which are used as aggregates for concrete, cement, and mortar as well as for building roads and waterways. Although in many industrial countries the value of their annual production is much higher than that of all metallic ores together, much less attention has been paid to them than to the "classic" mineral commodities. This is because there is apparently no difficulty of providing them in very large quantities. In fact, the global reserves of these bulk commodities are practically unlimited. But their exploitation and utilization involve very obvious conflicts in the use of land, and the local availability of near-surface bulk commodities is thus in many cases restricted.

Just as for near-surface bulk commodities, no definite information is available on the global availability of water and soil. Such data exist for many countries, but apparently no global inventories have been made, in contrast to other natural resources. It must be expected that the water and soil resources used to the present represent only a small percentage of the total available. Thus, the global availability of these resources is not endangered, but regionally, for example in large semi-arid areas, the difference between availability and utilization is very small, does not exist, or is even negative because of overuse.

\section{Environmental Impact of Mineral Resources}

During the last five decades, mineral raw materials have been consumed in larger quantities than during the entire history of mankind. Consumption (i.e. exploitation, concentration and use) will continue to increase in the future

\section{PHOSPHATE}

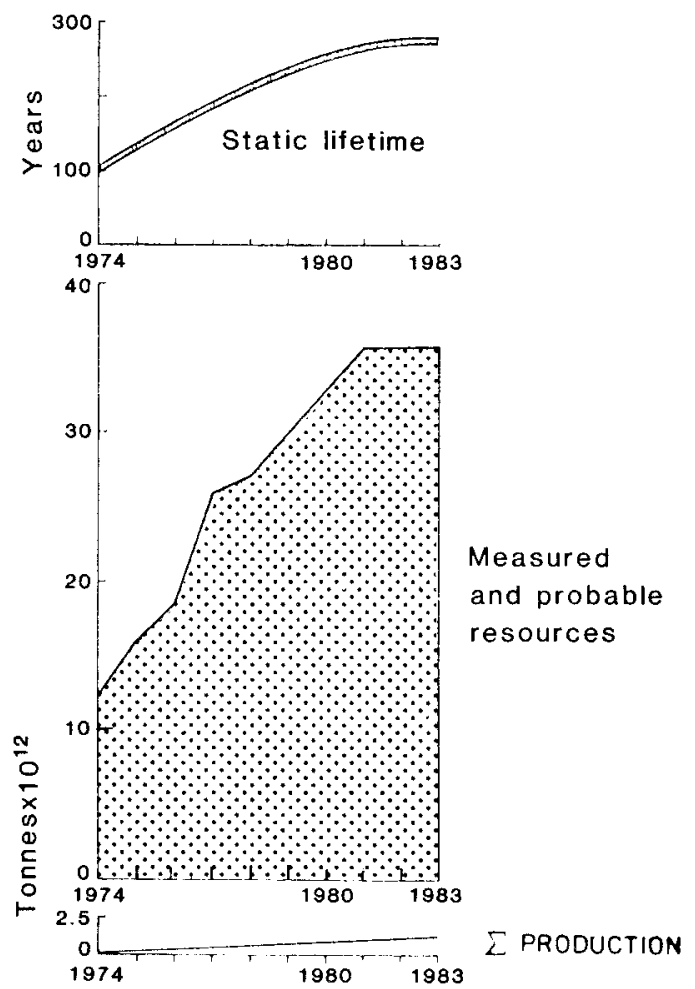

Figure 5: Cumulative production, resources and static lifetime of phosphate since 1974. After Bender and Delisle (1984). 
and is one of the reasons, probably even the main one, for environmental change. It influences the environment in an extremely large number of ways, and the very complicated chains of cause and effect have not yet been sufficiently investigated. Some of the factors by which the consumption of some mineral resources influence the environment are discussed in the following.

Exploration for and exploitation of hydrocarbons and coal can influence hydrogeological systems, may contaminate water and soil, and may lead to the subsidence of land. The waste products of such activities consist mainly of saline water, gases released into the atmosphere, and, in the case of coal mining, tailings. Research shows, however, that depending on the situation, harmful impacts on the environment can be reduced or avoided with modern technology. The same is true for uranium mining, for which groundwater contamination is the main hazard.

The upgrading and processing of these energy resources should not cause significant changes in the environment. Upgrading of coal produces large amounts of tailings that may influence the environment in a detrimental way. Considerable amounts of gases escape into the atmosphere when coke is produced. Processing of uranium and storage of the tailings without endangering the environment are possible only when a detailed geological investigation of the local situation has been made and appropriate technical measures are taken.

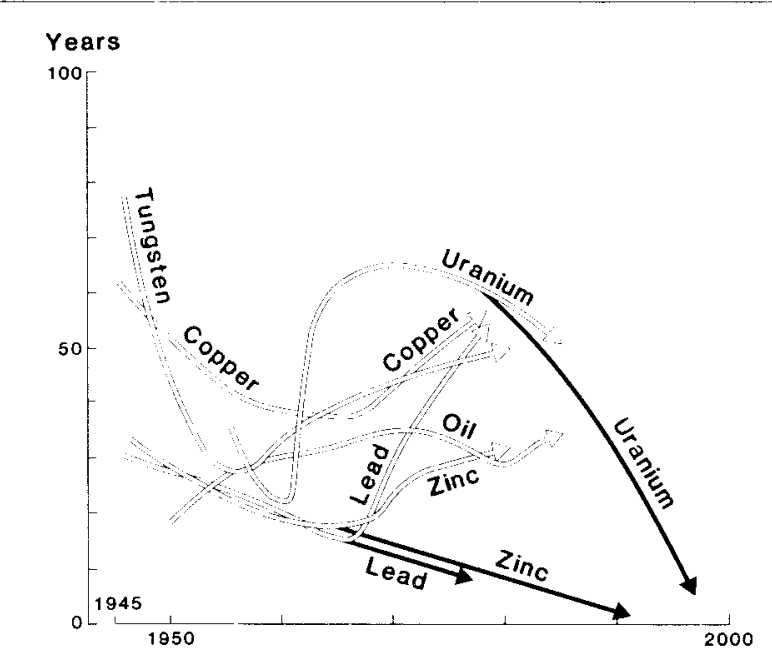

Figure 6: Static lifetimes of some important commodities. The lifetimes as predicted by the "Club of Rome" (Meadows et al., 1972) are shown as solid black curves.

The principal reason for contemporary global change is the use of energy resources, especially the combustion of oil, gas and coal with its effect on the atmosphere, biosphere and lithosphere. Sulphides and nitrates are the major cause for "acid rain," which can lead to the acidification of soils and lakes, to the mobilization of toxic metals and to other harmful influences on the environment. Because of the combustion of fossil fuels the carbon dioxide content is increasing in the atmosphere, with the potential of endangering climatic balances. An example of another effect on the lithosphere is shown in Figure 7, which illustrates lead contamination of the soil along main roads, due to the combustion of leaded gasoline. The use of uranium has presented the geoscientists with a particularly great responsibility, that of finding sites for the disposal of radioactive wastes in the geological medium, sites that must be safe for millenia.
The environmental effect of copper consumption may to quoted as an example for all metallic ores. The exploitation of copper ore "consumes" large areas, especially wheti low-grade ores are mined. The tailings can affect the environment due to their sulphur and heavy-metal content, and groundwater systems can be disturbed or contaminated by the mining process. In many mining areas, the transpoit and especially the concentration of metallic ores hith contaminated surface waters, groundwater, and soil with heavy metals.

The use of metals and metallic waste products also contr:butes to environmental changes. An example for copper is shown in the Geochemical A tlas of the Federal Republic of Germany (Fauth et al., 1985). Copper sulphate has bent used for centuries as a pesticide in the old grape-growing areas of Germany. These areas now coincide with distine: copper anomalies.

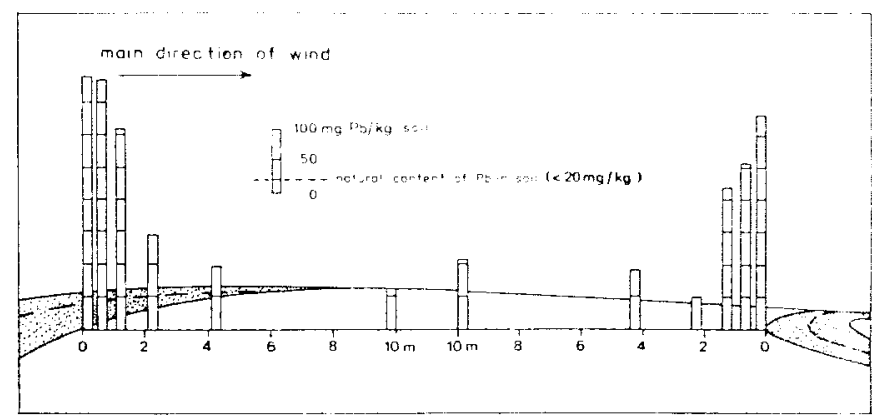

Figure 7: Lead contamination in $A_{h}$-soil horizor: along roadsides (Theodor-Huess-Ring, Kiel). After Aust and Becker-Platen, 1985.

The exploitation of near-surface bulk commodities also uses large areas and may affect groundwater systems. Especially in densely populated areas there may be conflicts with other claims for the use of the land, such as the utilization of soil for agriculture, groundwater exploitation, road construction or urban development. The contribution of upgrading these resources to environmental change is small, but that of their utilization, however, may be considerable. The construction of roads, reservoirs, canals, housing and business may cover large areas with concrete.

The part of the geosphere in which anthropogenic environmental changes are most distinctly recorded and have the most obvious impact on the environment concerns water and soil. These include the clearing of forests, resulting in soil erosion and a lowering of the water table, and groundwater exploitation in arid and semi-arid areas, leading to overgrazing and desertification. The irrigation of insufficiently drained soils can cause salinization of the soil. The emission of hazardous substances is a contributing factor to acicification of the soil and the death of forests. Over applic: tion of fertilizers can cause contamination of groundwater with nitrate and other pollutants, and groundwater mining may lead to a lowering of the water table and desiccation of the soil. Likewise, the mining of metallic ores may to accompanied by contamination with heavy metals of the soil surface water, and groundwater and the extraction of salt can be accompanied by their salinization.

Coping with Environmental Changes: Recommendations for the Geosciences

In order to plan something, one must know what is avaitable. Thanks to intensive geological research and intern ational cooperation, the present global availability of enery resources and metalliferous ores can be estimated rather well. The global potential of useable water, especially 
groundwater, and soil is, however, not so well known. An inventory of the "status quo" of these resources should be initiated with international cooperation and on the basis of uniform criteria.

Planning for the future also requires a knowledge of what was neglected in the past and what the consequences were. Therefore, a global inventory should be compiled of case histories in which exploitation, concentration and use of mineral resources had a particularly serious impact on the environment. This listing should include energy resources, metalliferous and non-metalliferous ores, near-surface bulk commodities, as well as water and soil. The environmental changes should be quantified. Just like the status quo inventory that of case histories should be prepared using uniform criteria so that national compilations can be compared one with another.

There is a serious conflict between the different claims on the geosphere. With a steadily growing world population, this conflict between competing claims on the non-reproducable lithosphere will increase. This development is inevitable, irreversible and a logical consequence of industrialization.

In any given area that cannot be enlarged, there may be many compelling claims on the lithosphere. These include its use for urban development, traffic routes, waste disposal sites, and nature preservation, use of the soil for agriculture and forestry, and groundwater exploitation, versus groundwater protection areas. The utilization of near-surface bulk commodities may have to be reconciled with the settingaside of reserve areas for natural resources; the utilization of mineral deposits at greater depths may likewise be in conflict with reserve areas for these deposits.

In the past, the lack of land-use planning or planning without considering the availability of and access to potential mineral resources caused enormous financial losses to national economies, as well as rather unquantifiable environmental impacts. It is recommended, therefore, that international, interdisciplinary models be set up for landuse planning in type areas whereby all aspects needed for landuse planning are taken into consideration, e.g. availability, potential availability, geotechnical safety, and protection of the environment.

Research on environmental change is necessary both for prevention, that is to avoid damages, and for rehabilitation in eases where damage has already occurred. Appropriate measures can be taken if the complex relationships between cause and effect are known. Therefore research, especially in the geosciences, must be intensified to determine the chains of cause and effect triggered by making mineral resources available.

For example, geoseientists in many countries are working on the behaviour of hazardous substances (e.g. nitrates, hydrocarbons, metals, pesticides) in the unsaturated zone of the soil. What changes do they undergo? How does the soil type affect this behaviour? What are the mechanisims of filtration, adsorption, and desorption in the soil? Which pollutants reach the groundwater and in what form? Which ones are taken up by the biosphere? To what extent are the heavy-metal concentrations in the environment, of anthropogenic as compared to natural origin? To solve these problems, type areas with different climatic and geographic conditions should be investigated, in international, interdisciplinary, cooperative programs.

Research on preventive measures should proceed in the same way. The focus here should, for example, be on protection of mineral resources availability and of groundwater, the underground storage of bulk commodities (e.g. hydrocarbons, geothermal energy), storage of solid toxic wastes above and below ground, and the injection of liquid toxic wastes underground.
Cooperation is also recommended for research on measures for the restoration of environmental changes that have occurred. The objective of this work should be to develop for different type areas, ways to ameliorate contaminated soil, and to reclaim mined-out areas. Measures are also needed to prevent the further distribution of hazardous substances from tailings, further land subsidence caused by the mining of mineral commodities, and the dispersal of toxic wastes from waste disposal sites above and below ground.

\section{Conclusions}

For the foreseeable future, the physical depletion of mineral resources will not be a global problem. However, making them available and using them will increasingly cause environmental changes, such as are already clearly recorded in the lithosphere, and the geosphere as a whole. International and interdisciplinary research in the field of geological sciences is of major importance for solving problems of the changing environment. If this is not intensified, and indeed soon, our beautiful, blue planet Earth may change to a dirty grey-brown.

Dr. F.K. Bender (Oberhain 17, D-3509 Spangenberg, F.R.G.) was from 1974 to 1985 the President of both the West German Federal Institute for Geosciences and Natural Resources (BGR) and the State Geological Survey of Lower Saxony. He has worked as a petroleum geologist in Germany, Turkey and Brazil, and as a BGR geologist undertook assignments also in Italy, Jordan and Paraguay. He is now a private consultant.

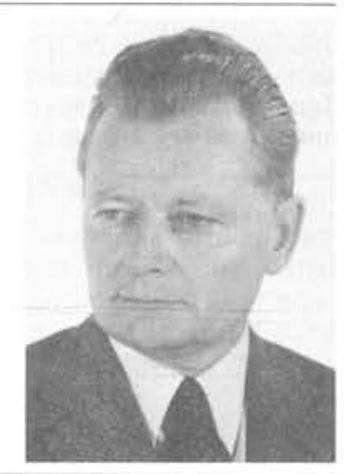

\section{References}

Anon., 1971. World Survey of Phosphate Deposits, 3rd Edition. The British Sulphur Corp. Ltd., London, 180p.

Anon., 1980. World Survey of Phosphate Deposits, 4th Edition. The British Sulphur Corp. Ltd., London.

Anon., 1980. World Metal Statisties, Copper World Mine Production. World Bureau of Metal Statistics.

Anon., 1983. Untersuchungen über Angebot und Nachfrage mineralischer Rohstoffe. XVIII. Phosphat, Bundesanstalt für Geowissenschaften und Rohstoffe und Institut für Weltwirtschaft an der Universität Kiel, Hannover-Kiel, 408p.

Aust, H. and Becker-Platen, J. D., 1985. Angewandte Geowissenschaften in Raumplanung und Umweltschutzé. In: Bender, F. (ed.), Angewandte Geowissenschaften, Band III, Ferdinand Enke Verlag, Stuttgart, 674p.

Bender, F, and Delisle, G., 1984. Wachsende Rohstoffprobleme trotz wachsender Rohstoffreserven. Geologisches Jahrbuch, Reihe A., v. 79, Hannover, p. 15-39.

Fauth, H., Hindel, R., Siewers, U. and Zinner, J., 1985. Geochemischer Atlas Bundesrepublic Deutschland. Bundesanstalt für Geowissenschaften und Rohstoffe. E. Schweizerbart'sche Verlagsbuchhandlung (Nägele und Obermiller), Stuttgart, 79p.

Fettweis, G.B., 1979. Die Situation der Vorräte an Kohle und Erdöl unter Berüicksichtigung von Gewinnungsund Transportproblemen. Bergund Hüttenmännische Monatshefte v. 24 , no. 8 , Springer, Vienna, p. 353-367.

Fettweis, G.B., 1981. Bauwürdigkeit und Verfügbarkeit von Steinkohlenvorkommen in der Welt - Zusammenhänge und Entwicklungen. Glüickauf, v. 117, no. 16, Essen.

Meadows, D.H., Meadows, D.L., Randers, J. and Behrens, W.W. III., 1972. The Limits to Growth. Universe Books, New York, 205p.

Schmidt, H. and Kruszona, M., 1982. Regionale Verteilung der Weltbergbauproduktion und der Weltvorräte mineralischer Rohstoffe. BGR-Bericht, Hannover. Unpublished. 